\title{
Conservational tree growing by smallholder farm households: evidence from Gamo highlands of Southern Ethiopia
}

\author{
Malebo Mancha Massa ${ }^{1 *}$ (i) and Abdulaziz Mosa²
}

\begin{abstract}
Deforestation and environmental degradation were identified among the leading factors worsening risk exposure in developing countries. Conservational tree growing was found a permissible option and an awake up policy direction to curve down the problem in Ethiopia. However, the uptake of this practice is far from complete and the art has not been made to a level that could make households self-reliant at least in tree resources, particularly in the highlands. The objective of this study was to identify the decisive factors that influence conservational tree growing behavior of smallholder farm households in Gamo highlands of Southern Ethiopia. The study was based on survey data collected from 11 villages in 2011/2012. A multi-stage sampling technique was used to select 335 farm households. Structured interview questionnaires and observations were used to collect primary data. Descriptive and inferential statistics and logistic regression model were used to analyze the data. The key findings showed that a host of factors significantly influenced smallholders' decision to practice conservational tree growing. The study found that tree growing experience, farm size, and availability of suitable land area for tree growing and cash income from sales of trees were the significant factors explaining the variation in conservational tree growing behavior of households. We also observed old-aged trees in traditionally protected areas. Among others, funeral and mystical sites host large number of longlived indigenous tree species than private farms in Gamo highlands of southern Ethiopia. Based on the findings, the study concluded that intra-farmer experience sharing, and support to efficient indigenous institutions and rural tree markets as potential entry points for mitigating deforestation and developing environmentally sustainable agriculture.
\end{abstract}

Keywords: Conservational tree growing, Gamo highlands, Ethiopia

\section{Background}

Risk exposure identified as one of the typical features of farming in developing countries limits income generating and hence affects welfare gaining capacity of farmers (Dercon 2004). The problem is serious in the horn of Africa where the economy is dominated by rain-fed smallholders' agriculture (Fulginiti et al. 2004; IPPC 2007; FAO 2011; FAO et al. 2011). Ethiopia is not an exception (FAO 2001; Di Falco and Chavas 2009). There exist plenty of evidences that explore the wide prevalence of

\footnotetext{
*Correspondence: malebo2004@gmail.com

${ }^{1}$ Department of Economics, Arba Minch University, P.O. Box 21, Arba

Minch, Ethiopia

Full list of author information is available at the end of the article
}

risk especially in the highlands of the country (FAO 1984; Bishaw 2001; Pender et al. 2001a, b; Dercon 2004; Pender and Gebremedhin 2007; Di Falco and Chavas 2009; Bekele and Mekonnen 2010; Zeleke and Bliss 2010; Federal Democratic Republic of Ethiopia 2011).

Deforestation was identified among the leading factors worsening the aforementioned problems. It intensifies environmental degradation, global warming, biodiversity loss and desertification and aggravates farmers exposure to regular weather shocks, climate change, and crop failure (Bishaw 2001, 2009; Bekalo and Bangay 2002; Dercon 2004; IPCC 2007; Yesuf et al. 2008; Bekele and Mekonnen 2010). With these externalities, market prices fail to reflect resource scarcity and individual members face insufficient incentives to adopt 
eco-friendly measures. This is serious in areas where people's livelihoods heavily depend on forest resources (Tietenberg 1992). It has an implication to a sustainably increase in farm productivity and agricultural output in vulnerable areas such as Ethiopia in general and in the Ethiopian highlands in particular. This is possible through better and more effective use of technologies conserving land and biological resources.

Empirical studies identify variety of technologies that enhance agricultural productivity, rural income and environmental quality. Agro-forestry and conservational tree growing (Bishaw 2001, 2009; Abebe 2005; Deininger and Jin 2006; Zeleke and Bliss 2010), tillage and composting (Kassie et al. 2009), soil bunding (Bekele 2005), and terracing (Deininger and Jin 2006; Pender and Gebremedhin 2006; Kassie and Holden 2006) are appealing options available in Ethiopia.

Among others, conservational tree growing founds a permissible option at least for some basic reasons. They are visible investments consistent with the notion of sustainable development set forth by the world commission on environment and development. It can also serve as a solution to the falling farm productivity and per head incomes observed in the last decades (World Commission on Environment and Development 1987; Deressa et al. 2009; Molua 2009; Pender and Gebremedhin 2007; Kassie et al. 2008, 2009, 2010; Melillo et al. 2011; Di Falco et al. 2011). Conservation has become critical because the world population has increased over the years and more food needs to be produced every year.

Trees can also uphold soil moisture, maintain biodiversity balance, safeguard erosion, reverse land and biological degradation, conserve organic matter of the soil and reduce soil nutrient loss, provide shades for crops, and improve land productivity (Bishaw 2001; Kassie et al. 2010). As trees rely to a greater extent on renewable local and farm specific resources (Lee 2005), they can expand income-generating opportunities for the poor, and hence resolve financial risk of buying technology inputs and food goods (Hogset 2005). Similarly, trees can support food security by either directly producing food goods or indirectly providing inputs for the production of food goods and/or supplying fuelwood for cooking food (Belsky 1993). Based on these evidences, conservational tree growing is a solution for environmental degradation, agricultural productivity, biodiversity balance, poverty reduction and hence for sustainable development.

Conservational tree growing is awake up policy direction in Ethiopia. Specifically, it is strongly promoted as part of climate resilient green economy strategy plan (Federal Democratic Republic of Ethiopia 2011). Furthermore, it is robustly recognized as an initiative to reverse the extensive land degradation, to protect the adverse effects of environmental degradation and climate change, and to build a green economy that realize the country's ambition of reaching middle income economy before 2025 (Federal Democratic Republic of Ethiopia 2011). Being a traditional technology one can expect that trees can be adopted with less risk as traditional practices in agriculture have been perceived as less risky than modern innovations (Feder and Zilberman1985; Griliches 1957). Puzzling, the uptake is far from complete and the art has not been made to a level that could make farm households self-reliant in tree resources, particularly in the highlands.

However, large differences are observed between households and villages. Some farmers and villages extensively plant and grow trees while some others do small and the rest do none (Abebe 2000; Admassie 2000; Bishaw 2001; Bekalo and Bangay 2002; Zeleke and Bliss 2010). These imply that the past re-afforestation programs launched in Ethiopia were not based on clear understanding of the incentives of and constraints on growers behavior. These programs were launched with the presumption that all farmers as an agent who can plant and grow more number and species of trees as long as seedlings are available (Zeleke and Bliss 2010). In Ethiopia, tree seedlings were supplied from public nurseries at least at free of charge or at subsidized prices (Zeleke and Bliss 2010). Thus, what determines conservational tree growing by farm households remains the central question of this study. Therefore, this study aimed to analyze and identify the main decisive factors that potentially influence conservational tree growing behavior of smallholder farm households in Gamo highlands of Southern Ethiopia.

Several factors might explain the variation in conservational technology adoption across households. Extension service, agro-ecology, availability of inputs, farm size, culture of people, institutions, proximity to markets, the return from the adoption, risk behavior of adopters, availability of initial capital and other socio-economic and demographic characteristics can determine technology adoption behavior, particularly in agriculture (Kassa 2003; Kebede and Yamoah 2009; Udry 2009). Factors affecting farmers' decision to plant and grow trees in Ethiopia have also been studied in Ethiopia (Zeleke and Bliss 2010). However, the scopes are narrowly defined with no or limited emphasis to conservational tree growing behavior. Thus, applied to Gamo highlands, we estimate factors meaningfully determine the variation in the adoption behavior of smallholder households towards conservational tree growing (OFATR).

OFATR in this study refers to growing a mix of both indigenous and non-indigenous trees an integral part 
of production agriculture specific to the study area else otherwise. OFATR in marginal areas of agricultural land improves crop yields, prevent soil erosion, preserve top soil for future abundant harvests, and helps with flood control. We find some important results that suggest smallholders fail to adopt OFATR or encouraged to adopt OFATR. It is not because of knowledge and information gaps. We also observe that cultural, religious, and old-aged funeral sites as a potential source for collecting extinct indigenous tree species in Ethiopia.

\section{Materials and methods}

\section{Description of the study area}

The study area, Gamo highlands, lies in a remote part of Ethiopia, within Gamo Zone of Southern Ethiopia, some $500 \mathrm{~km}$ to the south of Addis Ababa, the capital of Ethiopia. Gamo Zone is one of the administrative zones in the Ethiopian Southern Nations, Nationalities, and Peoples' Regional State. The Zone is composed of 14 districts (namely, Arbaminch Zuria, Bonke, Boreda, Chencha Zuria, Daramalo, Dita, Gacho Baba, Gerese, Kamba Zuria, Kogota, Kucha Alpha, Marta Gogle, Mirab Abaya and Selamber Zuria) and 4 town administrations (namely Arba Minch, Chencha, Kamba and Selamber). The administrative center of Gamo Zone is Arba Minch.

Based on the 2007 census conducted by the Central Statistical Agency of Ethiopia, Gamo Zone has a total population of $1,123,388$ of whom 558,297 (49.7\%) were men, $565,091(50.3 \%)$ were women and more than $90 \%$ were rural inhabitants (Central Statistical Authority of Ethiopia, 2008). Totally 229,791 households were counted in this Zone (198,949 rural and 30,842 urban), which results in an average of 4.89 persons to a household. The zone now has a total land area of 12,581.4 square kilometers and a projected total population of about 1.65 million, which make a population density of about 131.15 people. Gamo is the largest ethnic group (91.63\%) Census conducted in the Zone (Central Statistical Authority of Ethiopia, 2008). Thus, the name Gamo highlands and Gamo Zone are named for whose homelands live in this Zone.

Rising up from the west of twin lakes Abaya and Chamo, Gamo Highlands nearly range 100 kilo meters long between $06^{\circ} 02-27^{\prime}$ North latitude and $37^{\circ} 10-37^{\prime}$ East longitude (Samberg, Fishman et al. 2013). The Gamo Highlands comprise isolated mountain groups divided by deep valleys. Its topography characterizes undulating features that favour for the existence of diverse climates. An annual rainfall is bimodal and means annual temperature lies between 10 and 25 degree-centigrade (Samberg, Fishman et al. 2013). Its landscape is mostly hilly and ranges in up to 4,207 m altitude above sea level at Mount Gughe (Freeman 2002; Samberg, Fishman et al. 2013).
The economy of people in Gamo highlands, like many other rural areas in Ethiopia, depends on rain-fed agriculture, which feed and economizes almost all the people in the area. More than $90 \%$ of the populations depend on the products from this sector. Cultivation of 'Enset', potato and cereals (such as Barley and Wheat) form the basis of subsistence in the higher altitudes while Maize and Sorghum are important food sources on the lower slopes (Freeman 2002). Productivity in the area is very low because of small landholding, land fragmentation, and poor fertility of the soil due to severe erosion (Tesfaye, Fleskens et al. 2018).

In Gamo highlands, natural resources can be considered as opportunities and threats to the lives, if unmanaged. For example, the monsoonal rains and deep aquifers streaming from top highlands continuously feed the Sago, Zage, Maze, Domba, Deme, Kulano, Gogora, Saware, Wajifo, Baso, Harre, Kullufo, Sile and Elgo rivers. These in turn wear down and provide water and eroded loam soil for the people and the fertile fields in the lowlands (Desalegn 2007). Factually, the land of Gamo highlands were believed rich and referred as land of loam soil called 'ModhdhoBiita' (Malebo 2005). It was used to serve as a drought season home for the nearby lowlanders. However, nowadays, things have been reversing. As a result, the livelihoods of people in more recent times in Gamo highlands would tend to depend on subsistent agriculture and some off-farm economic activities such as labor-intensive petty trade, traditional weaving, wage work, and collection and sale of firewood are the outshining alternatives.

Due to environmental degradation, the unsustainable use of natural resources, poor performance of the agriculture and few income generating opportunities, most people diversify into the traditional labor-intensive weaving as alternative economic activity. Weaving was believed to be innovated by one of the Gamo tribes called 'Dorze' in Chencha district. This traditional industry as an off-farm income generating activity has been pushing significant proportion of the highlanders (including school age children) to migrate to the urban areas in other parts of Ethiopia. The problem is aggravated by the fact that population pressure and its density are high. Most farmers run small-scale agricultural production that has fragmented land holding and subsistent farming with less productive harvests to meet an everincreasing food and material needs of the people (Malebo 2005). Thus, insufficient rainfall, deforestation, poor land management practices, environmental degradation, soil erosion, soil infertility, population pressure, poor agricultural productivity, crop failure, and absolute poverty are the primary challenges hindering development in the Gamo highlands. 


\section{Materials}

The data used in this study was sourced from five districts located in Gamo highlands (Chencha, Dita, Deramalo, Arbaminch Zuria, and Bonke). We used detailed structured questionnaire survey for face-to-face personnel interviews with smallholder household heads who reside in eleven peasant associations called 'kebele' ${ }^{1}$ that were selected from the aforementioned five districts. The survey was conducted in $2011 / 2012$. The questionnaire was developed using a lesson acquired through informal pre-survey interviews with key informants of officials and professionals. The identification strategy followed sequential stages. First, as the role of heterogeneity across agents has been recognized in the technology adoption literature (Feder and Zilberman 1985), we purposively selected five districts that characterize varying agro-ecologies and tree coverage. Second; we randomly selected representative peasant associations from each district. Lastly, 335 proportionately sampled households were selected.

Agricultural extension workers working and living in each peasant associations carried out the survey. The interviewers got training about survey questionnaire and data collection techniques before the survey kicked off. The focal person for the interview was the head of the household. Household heads as a manager of the household has access to a wider availability of farm information and knowledge relative to other members of the household (Malebo 2005). Thus, they are the first line people who make almost all economic decisions refer to the household.We also conducted focused group discussions with government officials and professionals and direct personnel observation. These all enabled us to collect unfailing data that covered a broad range of socio-economic, demographic, institutional, behavioral, and farm specific characteristics.

\section{Methods \\ Determinants of technology adoption and the hypotheses on OFATR adoption}

There is a long and rich tradition of empirical research that seeks to explain farmers' adoption of agricultural innovations. As outlined by Feder and Zilberman (1985), researchers typically select a number of potential independent variables for inclusion in their analysis, based on prior theorizing and empirical tests. For our analysis of OFATR adoption, we selected a broad range of socioeconomic, demographic, institutional, behavioral, and farm specific characteristics. Table 1 describes the determinants of OFATR with their corresponding expected

\footnotetext{
${ }^{1}$ A peasant association is the smallest administrative unit in Ethiopia.
}

hypothesized relationships. These factors are grouped within three relevant categories. In this section, the influence of these factors is reviewed. The empirical significance of these factors in the adoption of conservational tree growing is exhaustively explored in latter stages of the paper.

Demographic factors Most empirical studies measure demographic factors either by labor availability, sex as a proxy for gender, age, and family size. Planting, nursing, and growing trees are labor-intensive endeavors in the study area. We expect that labor constraints can limit the adoptions. Arguably, the larger family size (FAMS) can associate with larger number of labor force and hence with larger number and category of trees grown. Likewise, younger people have a greater chance of acquiring and applying new knowledge and skill relative to older people (Rogers 1995; Sidibe 2005). In contrary, across age, people can develop experience and skill of doing things. These can make the age effect on tree growing behavior dilemmatic. Thus, we were unclear to hypothesize the role of household head's age (AGE) on the adoption of OFATR but expect a positive influence of family size on OFATR adoption behavior of smallholders (Table 1).

Gender (GEND) is another demographic factor that can influence the extent of adoptions. Being female or male-headedness proxy our gender variable. Females in the study areas play a role of household heads if and only if they were divorced or unmarried at all; if their husbands were dead; or when their son is too young to lead the household (Malebo 2005). This suggests the possibility of labor shortage with female-headedness. Owing larger labor force demand for OFATR adoption, we hypothesized a negative influence of female-headedness (GEND) or a positive influence of male-headedness and a positive association of active labor force (ACLF) availability to OFATR adoption (Table 1).

Socio-economic factors Socio-economic factors are also assumed to influence the adoption decisions. We use education, occupation, and wealth of the respondents as proxy for socio-economic factors. Technology adoption literature explains an easier and well familiar adoption of agricultural technologies with higher levels of education and training than those with lower levels (Tassew 2004; Sidibe 2005). Availability of skilled labor can ease such opportunities and likely to influence current technology adoption behavior of households. Thus, we hypothesized a positive influence of education (EDUC-CAT), tree growing experience (TGEXP), and training (TRAIN) on the adoption of OFATR. However, as labor demand in agriculture varies across seasons (peak during planting and harvesting and off-peak otherwise) the occupa- 
Table 1 Determinants of OFATR with expected hypothesized relationships

\begin{tabular}{|c|c|c|c|}
\hline Acronym & Description of variables & Measurement & Expected sign \\
\hline \multicolumn{4}{|c|}{ Dependent variable } \\
\hline OFATR & $\begin{array}{l}\text { Whether a household adopted } \\
\text { conservational tree growing or not }\end{array}$ & $\begin{array}{l}\text { Dummy ( } 1 \text { if grows ecological trees } \\
\text { including a mix of indigenous species, } 0 \\
\text { otherwise) }\end{array}$ & \\
\hline \multicolumn{4}{|c|}{ Independent variables } \\
\hline \multicolumn{4}{|c|}{ 1. Demographic factors } \\
\hline FAMS & Family size of the household & Number of people in the household & + \\
\hline AGE & Age of the household head & Formal age in number of years & $?$ \\
\hline GEND & Sex of the household head & Dummy ( 1 if female, 0 if male) & - \\
\hline \multicolumn{4}{|c|}{ 2. Socio-economic factors } \\
\hline EDUC & $\begin{array}{l}\text { Formal educational background of the } \\
\text { household head }\end{array}$ & $\begin{array}{l}\text { Categorical variable (no schooling }=1 \text {, grades } \\
1-4=2 \text {, grades } 5-8=3 \text {, grades } 9-12=4 \text {, and } \\
\text { grades above } 12=5 \text { ) }\end{array}$ & + \\
\hline OCCUP & $\begin{array}{l}\text { Occupation background of the household } \\
\text { head }\end{array}$ & $\begin{array}{l}\text { Dummy ( } 1 \text { if farming only, } 0 \text { if both farming and } \\
\text { others) }\end{array}$ & $?$ \\
\hline YTR & Source of household's income & $\begin{array}{l}\text { Dummy ( } 1 \text { if collects cash income from trees, } 0 \\
\text { otherwise) }\end{array}$ & + \\
\hline ACLF & Active labor force in the household & Number of active labor members & + \\
\hline TRAIN & $\begin{array}{l}\text { Training received about the role of tree } \\
\text { growing in environmental conservation }\end{array}$ & Dummy ( 1 if yes, 0 if no) & + \\
\hline TGEXP & Tree growing experience in the past & Dummy ( 1 if yes, 0 if no) & + \\
\hline \multicolumn{4}{|c|}{ 3. Agro-ecological and farm specific factors } \\
\hline SULNTR & $\begin{array}{l}\text { Availability of suitable land area for tree } \\
\text { growing }\end{array}$ & $\begin{array}{l}\text { Hectares of land area owned by the household } \\
\text { and located on sloppy mountainous areas }\end{array}$ & + \\
\hline FARMS & Farm size of the household & $\begin{array}{l}\text { Total hectares of land owned by the households } \\
\text { (in hectares) }\end{array}$ & + \\
\hline AVATR & Sufficient availability of seedlings & Dummy ( 1 if yes, 0 if no) & + \\
\hline HPP & $\begin{array}{l}\text { High potential perennial agro-ecological } \\
\text { zone }\end{array}$ & $\begin{array}{l}\text { Dummy ( } 1 \text { if the respondent belongs to HPP } \\
\text { zone, } 0 \text { otherwise) }\end{array}$ & \\
\hline $\mathrm{HPC}$ & High potential cereal agro-ecological zone & $\begin{array}{l}\text { Dummy ( } 1 \text { if the respondent belongs to HPC } \\
\text { zone, } 0 \text { otherwise) }\end{array}$ & \\
\hline LPC & Low potential cereal agro-ecological zone & $\begin{array}{l}\text { Dummy ( } 1 \text { if the respondent belongs to LPP } \\
\text { zone, } 0 \text { otherwise) }\end{array}$ & \\
\hline
\end{tabular}

Source: Authors' compilation

tion variable (OCCUP) might dually influence on OFATR adoption (Table 1).

On the one hand, sufficient availability of off-farm economic occupation can minimize work avoidance during off-peak periods. This might help to generate more income for those who supply more labor hours away from the household. Accordingly, one can expect positive income effect of off-farm occupation for the adoption of farm technologies. Arguably, higher income can build farmers ability to invest in productive technologies and other high pay-off inputs. It can also avert possible risks associate with the adoption. Yet, there are evidences that report negative role of off-farm economic occupation for the adoption of on-farm soil conservation measures. For example, Abera's (2003) study in Ethiopia estimates that off-farm economic occupations constrain household labor supply to on-farm economic activities. However, we expect that a household's sole dependence on onfarm incomes and generation of cash income from tree (YTR) can force them to plant more trees. Consequently, we hypothesized positive association between YTR and OFATR and remained unclear to hypothesize the association between off-farm occupations (OCCUP) and OFATR adoption (Table 1).

Agro-ecological and farm specific factors Farm size, land suitability, and proximity of farms to the nearest input and output markets are among the agro-ecological and farm specific factors assumed to determine technology adoption behavior. Agro-ecological factors were proxies by agro-ecological zones of the respondents. The agro-ecological zones of Ethiopian highlands were classified into 
Table 2 Major Agro-Ecological Zones of the Ethiopian Highlands

\begin{tabular}{lll}
\hline $\begin{array}{l}\text { Agro-ecological } \\
\text { zones }\end{array}$ & Climate & $\begin{array}{l}\text { Growing period } \\
\text { in number } \\
\text { of days }\end{array}$ \\
\hline HPP zone & Warm and more humid & Mainly $>240$ \\
HPC zone & $\begin{array}{l}\text { Intermediate rainfall } \\
\text { LPC zone }\end{array}$ & $\begin{array}{l}\text { Uigh vally }>180 \\
\text { drought }\end{array}$ \\
\hline
\end{tabular}

Source: Bishaw (2009)

three broad major categories: (i) the high potential perennial (HPP) zone, (ii) the high potential cereal (HPC) zone, and (iii) the low potential cereal (LPC) zone (Table 2). These often were defined in terms of temperature, stored soil moisture and number of days in a year that plants grow without irrigation (Bishaw 2009). The study incorporated these agro-ecological variables to control for all the unobserved agro-ecology specific factors associated with the adoption of OFATR in the smallholder farmers. We expect larger adoption of conservational trees in LPC zone than the other two as it characterizes high variability of climate and occasional occurrence of droughts (Bishaw 2009).

As far as farm specific factors are concerned, we use farm size, land suitability for tree growing and sufficient availability of seedling sources. A basic possible hypothesis on-farm size is that the adoption of an innovation will tend to take place earlier on larger farms than on smaller farms. This can be largely due to cost issues. For instance, Feder and O'Mara (1981) demonstrate that fixed transaction costs associated with the adoption innovations prevents small farms from adopting technologies. Likewise, farm households with larger farm sizes (FARMS) are more likely to adopt agricultural innovations compared with those with small farms as they can afford to devote part of their fields to the adoption of innovations. Land suitability for tree growing (SULNTR) is also another important farm specific factor that might influence farmers' technology adoptions. The availability of more mountainous land area, the greater the likelihood of adopting conservational investments. Sufficient availability of seedling sources (AVATR) is also basic as investors use factor inputs for production. We thus expect that OFATR is positively associated with SULNTR, AVATR, and FARMS (Table 1).

\section{Model specifications}

This study used a mix of both descriptive and inferential statistics, and econometric tools. Initially, the inter-relation between the potential predicators was analyzed by spearman correlation and then regression analysis was utilized principally. Since our observations take limited categories with zero values on the dependent variable the orthodox Ordinary Least Squares (OLS) regression models cannot properly accommodate the data. This failure directed us to utilize estimators built on the principle of maximum likelihood (MLE) estimators. The most common of these models used in the adoption literature are the logit and the probit. As Amemiya (1985), Wooldridge (2000) and Verbeek (2004) conclude that the choice of which model to use cannot be justified theoretically.They estimate almost similar results. However, there are empirical suggestions that persuade us to prioritize between them. Arguably, logistic regression analysis provides response probability estimates that are asymptotically consistent and computationally easier to use than probit (Pindyck and Rubinfeld 1981).

Following this framework, logistic modeling approach founds customary in empirical studies that examine factors determining technology adoption, particularly in agriculture (Green and Ng'ong'ola 1993; Chaves and Riley 2001; Tadesse and Belay 2004; Asfaw and Admassie 2004; Mercer, et. al., 2005; Iqbal et al. 2006; Zeleke and Bliss, 2010). Evidently, the assessment of factors influencing the adoption of integrated pest management for coffee in Colombia (Chaves and Riley, 2001), the adoption of fertilizer use in Africa (Green and Ng'ong'ola, 1993) and the assessment of factors determining rubber-tea intercropping by the smallholder farmers in Sri Lanka (Iqbal, et al, 2006) are worth mentioning. Based on these previous studies, we apply the logit model to estimate factors influencing household's decision to grow conservational trees.

A common starting point for logit model is a 'random utility framework'. According to this framework, the actual utility level of OFATR adoption to each household is unknown. However, the household chooses to adopt OFATR if the utility gained from adoption is larger than the utility of non-adoption (Verbeek 2004; Asfaw and Admassie 2004). Some of the possible utility gains associated with conservation agriculture at the farm level include increase in soil fertility and moisture retention, resulting in yield increase, decreasing yield variations and greater food security and that of utility losses include perceived risk to farmers because of technological uncertainty and acquiring of new management skills (FAO 2001). Therefore, for each household, we can write the utility difference between OFATR adopters and nonadopters by latent variable, $T_{i}$, as a function of observed covariates, $\mathrm{X}_{\mathrm{i}}$, and unobserved covariates, $\varepsilon_{\mathrm{i}}$. 


$$
T_{i}^{*}=X_{i}^{\prime} \beta+\varepsilon_{i}
$$

As utility is random, the ith household will choose to adopt OFATR if the utility difference exceeds a certain threshold level, which can be set to zero. Thus, for the household $i$, the probability of OFATR adoption is given by:

$$
\begin{aligned}
& \mathbf{P}_{\mathbf{r}}\left(\mathbf{T}_{\mathbf{i}}=\mathbf{1} / \mathbf{X}\right)=\mathbf{P}_{\mathbf{r}}\left(\mathbf{T}_{\mathbf{i}}^{*}>\mathbf{0}\right)=\mathbf{P}_{\mathbf{r}}\left(X_{i}^{\prime} \beta+\varepsilon_{\mathrm{i}}>\mathbf{0}\right)= \\
& \mathbf{P}_{\mathbf{r}}\left(\varepsilon_{\mathbf{i}}>-X_{i}^{\prime} \beta\right)=\mathbf{G}\left(X_{i}^{\prime} \beta\right)
\end{aligned}
$$

where $\mathrm{G}($.$) is the (cumulative) logistic distribution func-$ tion of the error term, $\varepsilon_{\mathrm{i}}$.

Given the latent variable $\mathbf{T}_{\mathbf{i}}$, the general form of the logit model can be defined as:

$$
\begin{aligned}
& T_{i}^{*}=\mathrm{X}_{i}^{\prime} \beta+\varepsilon_{\mathrm{i}} \\
& T_{i}=1 \text { if } T_{i}^{*}>0 \\
& T_{i}=0 \text { if } T_{i}^{*} \leq 0
\end{aligned}
$$

where $T_{i}=1$ is the latent variable representing OFATR adoption and $\mathrm{T}_{\mathrm{i}}=0$ non- adoption.

In the logit model, the logistic distribution function $\mathrm{G}$ (.) is given as:

$$
G\left(Z_{i}\right)=P_{i}=\frac{\exp \left(Z_{i}\right)}{1+\exp \left(Z_{i}\right)}=\frac{e^{Z_{i}}}{1+e^{Z_{i}}}=\frac{e^{\beta_{0}+X \beta}}{1+e^{\beta_{0}+X \beta}}
$$

In the logistic distribution function (4), $\mathrm{p}_{\mathrm{i}}$ is the probability of adopting OFATR. Then, $1-\mathrm{p}_{\mathrm{i}}$ that represents the probability of not adopting OFATR is given as:

$$
1-P_{i}=\frac{1}{1+e^{Z_{i}}}
$$

The odds ratio that represents the ratio of the probability of OFATR adoption occurring $\left(\mathrm{p}_{\mathrm{i}}\right)$ to that of not occurring $\left(1-\mathrm{p}_{\mathrm{i}}\right)$ is given as:

$$
\frac{P_{i}}{1-P_{i}}=\frac{\frac{e^{Z_{i}}}{1+e^{Z_{i}}}}{\frac{1}{1+e^{Z_{i}}}}=e^{Z_{i}}
$$

Taking the natural log of the odd ratio (Eq. 6), we have the standard form of the logit model estimating the likelihood of OFATR adoption by smallholder farm households:

$$
L_{i}=\ln \left(\frac{P_{i}}{1-P_{i}}\right)=\ln \left(e^{Z i}\right)=Z_{i}
$$

where, $\mathrm{L}_{\mathrm{i}}$ is the $\log$ of the odds ratio in favor of the adoption (also called the logit).

The logit is linear in explanatory variables $\left(\mathrm{X}_{\mathrm{i}}\right)$ and in parameters $\left(\beta_{\mathrm{i}}\right)$ (Wooldridge 2000). Therefore, for an individual farm household, we construct $\mathrm{L}_{\mathrm{i}}$ as a linear function of explanatory variables $\left(\mathrm{X}_{\mathrm{i}} \mathrm{s}\right)$ and unknown parameters $\left(\beta_{\mathrm{i}}\right)$. The unknown parameter $\beta_{\mathrm{i}}$ associated with each $X_{\mathrm{i}}$ is determined by an iterative process that makes use of a maximum likelihood estimate (Wooldridge 2000). Therefore, the empirical model for estimating the determinants of OFATR adoption status based on the logit model can be specified as:

$$
\begin{aligned}
& \mathbf{L}_{\mathbf{i}}=\beta_{\mathbf{0}}+\beta_{\mathbf{1}} \mathbf{G E N D}_{\mathbf{i}}+\beta_{\mathbf{2}} \text { FAMS }_{\mathbf{i}}+\beta_{3} \mathbf{A G E}_{\mathbf{i}}
\end{aligned}
$$

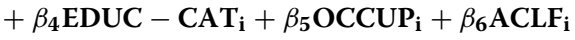

$$
\begin{aligned}
& +\beta_{7} \text { FARMS }_{\mathbf{i}}+\beta_{\mathbf{8}} \text { YTR }_{\mathbf{i}}+\beta_{\mathbf{9}} \text { TGEXP }_{\mathbf{i}}+\beta_{10} \text { AVATR }_{\mathbf{i}} \\
& +\beta_{11} \text { TRAIN }_{\mathbf{i}}+\beta_{12} \text { SULNTR }_{\mathbf{i}}+\beta_{13} \text { HPP }_{\mathbf{i}}+\beta_{14} \text { HPC }_{\mathbf{i}}+\varepsilon_{\mathbf{i}}
\end{aligned}
$$

The choice of the explanatory variables included in Eq. (8) is based on previous empirical evidences and their description and measurement are as defined in Table 1. Since the parameters $\beta_{\mathrm{i}} \mathrm{s}$ are unbiased and normally distributed, we used an analogue of student's t-test to test the significance of the regression model (8). Throughout the estimation, we use $t$ statistics based on standard errors that are robust to heteroskedasticity. The significances of the coefficients of the variables presented in the logistic model were tested using a log-likelihood ratio assuming a chi-square ( $\mathrm{x} 2)$ data distribution (Pindyck and Rubinfeld 1981). All the analyses were run using a mix of STATA and Microsoft offices excel program software packages.

\section{Results and discussions}

\section{Characteristics of the respondents}

Descriptive statistics of all the variables used in the study are shown in the Table 3. The dependent variable OFATR is a dummy variable that takes the value of 1 if the respondent grows a mix of indigenous species of trees and 0 if otherwise. The results for this variable show that $39.4 \%$ (132) of the households surveyed grow conservational trees while $60.6 \%$ do not Fig. 1 .

The study used availability of active labor force (ACLF), gender (GEND), family size (FAMS), and age (AGE) as proxies for demographic characteristics. The size of ACLF in the respondent's family system is a discrete variable representing number of adults who are member of the respondent's household, aged between 15 and 64 years and available for work. The average number of ACLF is 3.2 adult people with the minimum of 1 and the maximum of 13 implying the ACLF of the majority of the households is less than 4 . This might be due to the fact that majority of the younger adults are devoted to traditional weaving and/or migrated to urban areas. 


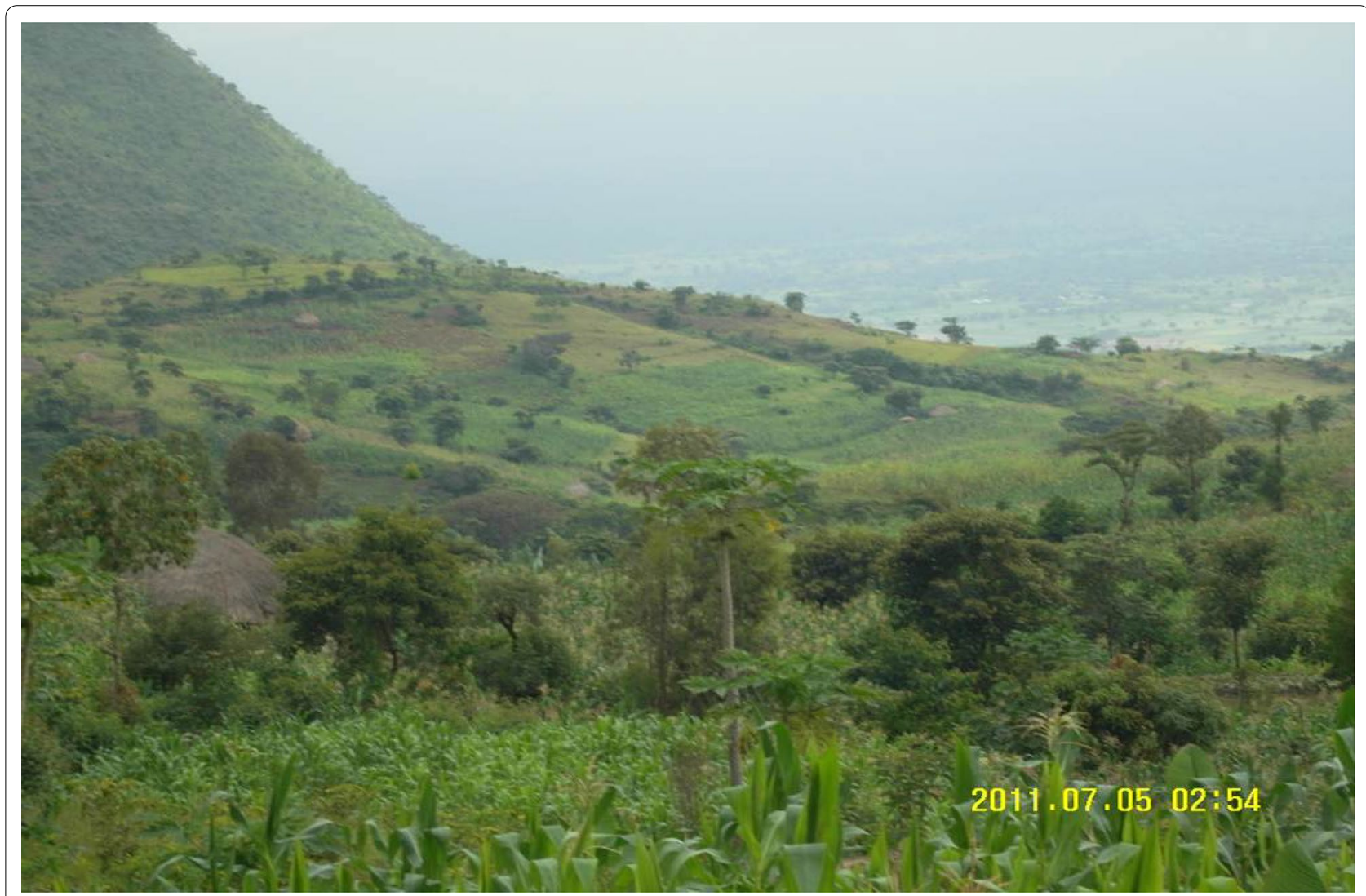

Fig. 1 OFATR as a conservation strategy by households in Deramalo district

\begin{tabular}{|c|c|c|c|c|c|}
\hline Variable & Observations & Mean & Std. dev & Min & Max \\
\hline OFATR & 335 & 0.394 & 0.489 & 0 & 1 \\
\hline GEND & 335 & 0.113 & 0.318 & 0 & 1 \\
\hline FAMS & 335 & 6.970 & 2.901 & 1 & 17 \\
\hline AGE & 335 & 43.776 & 10.646 & 20 & 75 \\
\hline EDUC-CAT & 335 & 2.501 & 0.692 & 1 & 5 \\
\hline OCCUP & 335 & 0.794 & 0.405 & 0 & 1 \\
\hline ACLF & 335 & 3.155 & 1.796 & 1 & 13 \\
\hline FARMS & 335 & 1.023 & 1.088 & 0.013 & 7.818 \\
\hline YTR & 335 & 0.259 & 0.439 & 0 & 1 \\
\hline TGEXP & 335 & 0.722 & 0.448 & 0 & 1 \\
\hline AVATR & 335 & 0.328 & 0.470 & 0 & 1 \\
\hline TRAIN & 335 & 0.600 & 0.491 & 0 & 1 \\
\hline SULNTR & 335 & 0.138 & 0.229 & 0 & 1.5 \\
\hline HPP & 335 & 0.281 & 0.449 & 0 & 1 \\
\hline $\mathrm{HPC}$ & 335 & 0.537 & 0.499 & 0 & 1 \\
\hline IPC & 335 & 0.182 & 0.386 & 0 & 1 \\
\hline
\end{tabular}

Source: Authors' compilations from field survey
The gender (GEND) status of the respondents is either male or female. It is included to identify the implications of gender differences on conservational decision-makings. From the sampled households $11.3 \%$ are female- and $88.7 \%$ are male-headed. Family size (FAMS) is a discrete variable representing number of people in the household. The average family size was 6.9 people with the minimum of 1 and the maximum of 17. The study proxied human capital status of households by their head's age (AGE), education level (EDUC-CAT) and tree growing experience (TGEXP). The respondent's tree growing experience in the past (TGEXP) is a dummy variable that took a value of 1 for those who have experience and 0 otherwise. Among the respondents, $72.2 \%$ have tree growing experience while the rest do not. The respondent's age (AGE) is a continuous variable representing age in number of years. The average age of the sample household heads is nearly 44 years with the minimum of 20 years to the maximum of 75 year old. Thus, majority of the household heads are aged on the high side of ages above 40 years. This might be because of the fact that some parents co-reside with son and daughter-in-law and because 


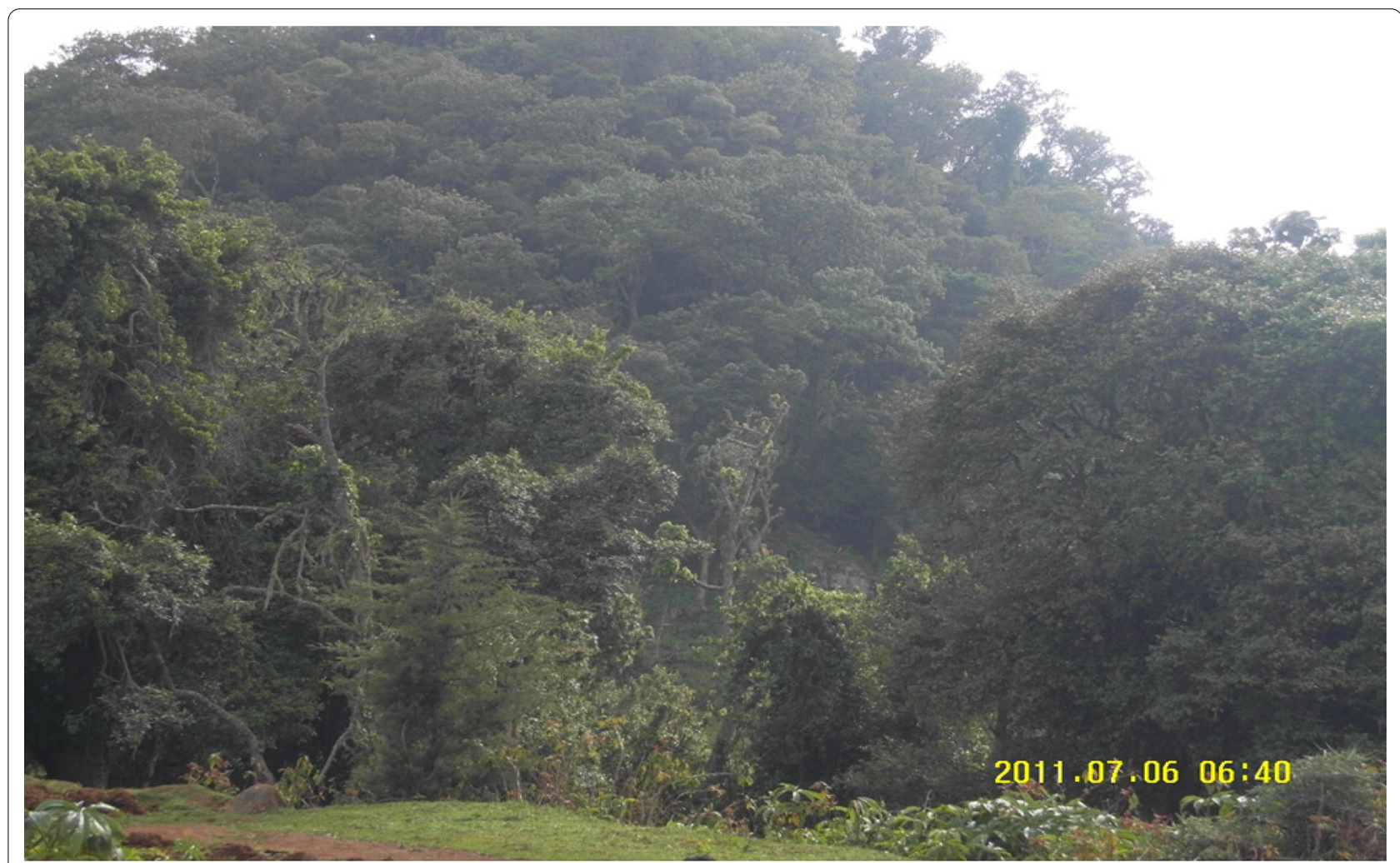

Fig. 2 Traditionally protected trees in Nagasa of Chencha

of age-selective migration of the younger male to urban areas (Malebo 2005).

The education variable is represented in categorical orders ranging from 1 to 5 with the average of 2.5 , which is equivalent to primary school level below grade 8. Average education levels are low because older generations in the study area are relatively less educated than younger generations. As Table 3 indicated, about $25.9 \%$ of surveyed households generate liquid cash income through sale of trees while the rest $74.1 \%$ do not. Moreover, as a component of socio-economic indicator, the study proxied occupation status of the households by a dummy variable that assume the value of 1 if the respondent household's head work solely on-farms and 0 if work on on-farm and off-farm activities. Accordingly, 20.6\% of farm households have an off-farm job while $79.4 \%$ exclusively work on-farms. Farm size (FARMS) is a continuous variable with the size of farms in hectares. This variable represents the land owned by household. As shown in the Table 3, the average size of farm or landholding is 1.02 hectares of land and there appears to be a wide range of variability in farmland ownership ranging from 0.01 hectares farm possession at the minimum to owning 7.82 hectares of farmland at the maximum.
The agro-ecological origin of the respondents shows that $28.1 \%$ are from HPP zone, $53.7 \%$ are from HPC zone, and the rest $18.2 \%$ are from LPC zone. Availability of seedling (AVATR) variable suggests that about $32.8 \%$ of the respondents have sufficient access to sources of seedlings while the rest $67.2 \%$ do lack. The study proxied land suitability for tree growing by number of hectares of the household's land located on sloppy mountains. If the household owns larger hectares of land area on mountainous slopes, the owner has very suitable land area for tree growing than cropping. About $43.9 \%$ of the respondents have more than $10 \%$ of their own land area on sloppy mountains. Training variable of the study indicate that about $60 \%$ of the respondents are either consulted information or received training on land and soil conservation measures while the other $40 \%$ do not.

The summaries of descriptive statistics for household who adopt OFATR and household who do not adopt OFATR are separately reported in Appendix 2 and Appendix 3, respectively. In general, majority of the households surveyed averagely fail to adopt OFATR. Most of those households who did not grow trees are male-headed with more than 43 years of age, host more than six people per household, and have less than four working age people in the household. Furthermore, these 
Table 4 Summary of the factors associated with OFATR adoption: The logit estimates

\begin{tabular}{|c|c|c|c|c|c|c|}
\hline \multirow[t]{2}{*}{ Variables } & Coefficients & $\begin{array}{l}\text { Robust standard } \\
\text { errors }\end{array}$ & $\mathrm{P}>/ \mathrm{Z} /$ & Coefficients & $\begin{array}{l}\text { Robust standard } \\
\text { errors }\end{array}$ & $P>/ Z /$ \\
\hline & \multicolumn{3}{|c|}{ Estimation 1 (Appendix 4) } & \multicolumn{3}{|c|}{ Estimation 2 (Appendix 5) } \\
\hline GEND & -0.681 & 0.522 & 0.192 & -0.688 & 0.536 & 0.199 \\
\hline FAMS & 0.043 & 0.062 & 0.488 & 0.021 & 0.065 & 0.740 \\
\hline AGE & 0.009 & 0.015 & 0.542 & 0.012 & 0.015 & 0.451 \\
\hline EDUC-CAT & 0.031 & 0.206 & 0.881 & 0.008 & 0.209 & 0.971 \\
\hline OCCUP & 0.241 & 0.342 & 0.481 & 0.291 & 0.353 & 0.410 \\
\hline ACLF & 0.013 & 0.102 & 0.897 & 0.036 & 0.106 & 0.737 \\
\hline FARMS & $-0.367^{* * *}$ & 0.159 & 0.022 & $-0.435^{* * *}$ & 0.175 & 0.013 \\
\hline YTR & $0.585^{* *}$ & 0.301 & 0.053 & $0.564^{*}$ & 0.303 & 0.063 \\
\hline TGEXP & $4.377^{* * *}$ & 1.055 & 0.000 & $4.559^{* * *}$ & 1.096 & 0.000 \\
\hline AVATR & 0.195 & 0.298 & 0.512 & 0.167 & 0.300 & 0.578 \\
\hline TRAIN & 0.387 & 0.296 & 0.190 & 0.343 & 0.300 & 0.253 \\
\hline SULNTR & $1.591^{* *}$ & 0.784 & 0.043 & $1.698^{* *}$ & 0.841 & 0.044 \\
\hline HPP & & & & -0.703 & 0.423 & 0.097 \\
\hline $\mathrm{HPC}$ & & & & -0.679 & 0.407 & 0.095 \\
\hline Constant & $-5.543^{* * *}$ & 1.257 & 0.000 & $-5.050^{* * *}$ & 1.279 & 0.000 \\
\hline Pseudo $\mathrm{R}^{2}$ & 0.278 & & & 0.284 & & \\
\hline Log likelihood & -162.137 & & & -160.785 & & \\
\hline
\end{tabular}

${ }^{*} P<0.1,{ }^{*} P<0.05$, and ${ }^{* * *} P<0.01$

Source: Authors' computation based on field survey

households on average hold more than 1.02 hectares of land area, attained education status below grade 8, work solely on small-scaled and fragmented farmlands, and have poor access to off-farm economic opportunities. On the other hand, the data also revealed that a household who plant and grow trees have acquired tree growing experiences in the past, use trees mainly for home consumption with low sales for cash. These households were informed about the importance of trees and own land area that can primarily be used for tree growing than for crop production and animal grazing. We also observed that there exist old-aged trees in traditionally protected areas of Gamo highlands. Among others, funeral and mystical sites host large number of long-lived indigenous tree species than private farms in the area (Fig. 2).

Factors determining the adoption of OFATR by smallholder farm households in the Gamo highland of Southern Ethiopia

In this section, we examine the partial correlation and main results exploring the determinants of conservational tree growing behavior of households specific to Gamo highlands of Southern Ethiopia. Initially the partial correlation analysis was performed. This was to assess the inter-relation of the factors that potentially affect the farmer's decision to adopt OFATR.
Appendix 1 summarizes partial and semi-partial correlation coefficients of the main factors associated with the decision to adopt conservational tree growing (OFATR) by smallholder farmers in Gamo highlands. Of the factors, six variables are significantly correlated $(\mathrm{P}<0.1)$ with the decision to adopt conservational tree growing and results consistent with the logit estimations. These factors are age of the household head (AGE) measured in years, farm size of the household measured in hectares of land area (FARMS), and cash income that households generate through sales of trees or tree goods measured in units of 'birr' value of the sales (YTR). Furthermore, past experience of growing trees proxied by dummy values of existence or non-existence (TGEXP) and land suitability (SULNTR) for growing trees measured in hectares of land area on mountains or very sloppy location are also associated to OFATR.

Likewise, to assess the relative contribution of significant factors we used a multivariate logistic regression analysis. Logistic estimates predicting the maximum likelihood for the factors that determine the adoption of OFATR behavior of farm households are presented in Table 4 . The estimates were made with and without controlling for agro-ecological dummies in order for capturing the unobserved factors specific to varying agro-ecologies. The logit estimation also founds significant at $1 \%$ level of significance; i.e., the log-likelihood ratio (regression deviance) 
is significant $(p<0.01)$ throughout the estimations, indicating that the model is statistically valid.

Based on t-probability values, smallholders' OFATR adoption behavior is positively and significantly associated to household's age (AGE), the existence of tree growing experience (TGEXP), household's capacity to generate cash income from trees (YTR) and the availability of suitable land area for tree growing (SULNTR). However, smallholders OFATR adoption decision is negatively related to the farm size available to the households (FARMS).

Among others, past tree growing experience is the most significant factor associated with tree growing behavior of smallholder farmers in the current Gamo highlands. In other words, households with past tree growing experience are more likely to adopt OFATR relative to household without such experience. Evidently, we demonstrate that significant number of farmers who grow trees in the past also plant and grow more number and species of trees in their present farms. This is consistent with the hypothesis we made so far and with the predictions that producers primarily specialize in the agricultural system in which they have past experiences.

The age variable is unpredictably resulted as it was unclearly hypothesized. The estimates indicate that this variable remains insignificant to explain the adoption behavior of households. This is inconsistent with Rogers's (1995) and Sidibe's (2005) estimates of the age influence on the technology adoption behavior of the adopters. Rogers (1995) and Sidibe (2005) demonstrate that younger people have a greater chance of acquiring and applying knowledge and skill than older people do. This does mean that people can develop experience and skill of doing things across age. However, unlike their argument, the estimates of the TGEXP variable in this study prove strong positive association to OFATR, which is evidently significant.

The availability of suitable land area for tree growing (SULNTR) is positively and significantly $(p<0.05)$ associated to OFATR adoption decision of households. Farm households who own more hectares of land in mountainous area (that is suitable for tree growing) are more likely to adopt OFATR relative to households who possess less mountainous land area. This result consistently supports our hypothesis. However, the estimates for farm size (FARMS) variable founds paradoxical. It disproves the fixed transaction costs hypothesis by Feder and O'Mara (1981): 'the adoption of an innovation will tend to take place earlier and larger on large farms than on small farms'. In contrary, we estimated strong negative association between FARMS and OFATR. The estimated coefficient reveals relatively high levels of OFATR by small holder farmers than large holder farmers. This may be because of the intensity of small holder farmers' use of abundant labour in combination with small land holdings. Our result also suggests the 'small-farm first' narrative by Schultz (1964): "small farmers are rational economic agents making efficient farm decisions." Environmentally friendly investment decisions may also be recognized as luxury for rich but a necessity for poor (Bekalo and Banguy 2002).

In contrast, estimates for gender of household heads (GEND), family size of the household (FAMS), and education status of the household head (EDUC-CAT) are inconsistent to support the hypotheses made so far, not significantly influence the variation in OFATR adoption and hence less likely to affect OFATR adoption decision of households. Likewise, the estimates for occupation category of the household (OCCUP), access to training and information (TRAIN), availability of seedlings (AVATR), availability of active working age labor force in the household (ACLF), and agro-ecological differences in the Gamo highlands all showed statistically insignificantly associated to OFATR. Thus, these factors are less likely to affect conservational tree growing behavior of smallholder farm households in Gamo highlands.

Specifically, we assumed farmers with formal education (EDUC-CAT) can have greater agricultural awareness relative to others with no formal education and this variable is assumed to have positive link to the adoption of OFATR. Unlike the hypothesis, the estimates show that EDUC-CAT is positively but insignificantly associated with OFATR. This reveals that education is less likely to influence conservational tree growing behavior of households in the study area. This is inconsistent with the conclusions by Tassew (2004) and Sidibe (2005). We also observe that households headed by educated people have relatively more number of educated labor forces in their family system than the uneducated one. In view of these, one can expect that more number of skilled labor forces in the family might pave the way for tree growing opportunities. However, the coefficient for EDUCCAT variable does suggest the reverse. This reminds us the narration by an old man in Chencha district of Gamo highlands - "I don't want my child will farm ... as I lived poor because of my farms". If this narration continues to hold and educated people leave farms before agricultural transformation, the future of rural Ethiopia, mainly for the highlanders, might not be bright. These suggest some cautious intervention and necessitate further analysis of the events in the smallholders' agriculture in Gamo highlands.

We expected that female-headedness can negatively influence OFATR adoption because of labor shortages and hypothesized that labor constraints of the family can limit the adoption of conservational tree growing 
(OFATR). Even if, the estimation results indicate femaleheaded household are negatively affect OFATR adoption but it is statistically insignificant and hence gender of the household cannot make a big difference in the adoption behavior of households. Similarly,even though the estimation result supports the hypothesis that household with larger number of family size (FAMS) and larger number of working age people (ACLF) in the family system tend to adopt OFATR than households with less family size and less number of active labor in Gamo highlands but these results are also statistically insignificant.

The variations in agro-ecological zones (for example, HPP, HPC and LPC) do not result any significant difference in the OFATR adoption behavior of household. In other words, irrespective of their agro-ecological location, similar factors influence farm households' OFATR adoption decisions. Although we hypothesized that availability of off-farm economic occupation (OCCUP) and OFATR adoption behavior are ambiguous, the model result indicate that having an off-farm job positively affects the likelihood of a farmer's OFATR adoption behavior but it is statistically insignificant and hence we find weak evidence that support the strong association between OCCUP and OFATR adoption.

On the contrary, the cash income that households generate from sales of trees from farms (YTR) meaningfully links to their OFATR adoption behavior. On the one hand, occupational differences that might cause variation on per head income of households founds insignificant to explain difference in the OFATR adoption behavior of households. On the other hand, income that can allow ease access to inputs finds insignificant to explain the variation in OFATR adoption. Therefore, though our estimates for the YTR variable do support Abera's (2003) study that he reports negative role of off-farm income in the adoption of soil conservation measures in Ethiopia, the path way through which income variable (YTR) links to tree growing behavior of farm households necessitates further scrutiny. This is soundly that availability of seedlings also founds less likely to explain OFATR adoption behavior of smallholders in Gamo highlands.

\section{Conclusion and policy implications}

The study has intended to estimate factors determining the adoption behavior of smallholder farm households towards conservational tree growing specific to Gamo highlands. The results indicated that as age of household heads increase and households get involved in tree growing experiences they tend to plant and grow more number and species of trees. This enables those to harvest more tree goods, earn more cash income from sales of trees and further plant and grow more number and species of trees, though it diminishes with age of household heads.
Paradoxically, households with larger resource base (mainly land) do not grow larger number and species of treeas compared to households with smaller resource base. Likewise, smallholder households fail to plant and grow conservational trees or encouraged to plant and grow conservational trees because they characterize varying experiences of tree growing in the past, ages of the household head, hectares of land area available to the households and its suitability for growing trees than cropping, and cash income generates from sales of trees and tree products.

We also observe that conflicts with adjacent farm household others might influence tree growing behavior of smallholders in Gamo highlands. In addition, we witness that cultural, religious, and old-aged funeral sites can be taken as potential sources for collecting becoming extinct tree species mainly in Gamo highlands of Southern Ethiopia. Thus, indigenous social organizations can serve as potential sources for collecting becoming extinct tree species in the smallholders' agriculture, mainly in Gamo highlands of Southern Ethiopia. These also suggest positive role of indigenous institutions for forestry development, poverty reduction and sustainable development in rural Ethiopia in general and in Gamo highlands in particular. Therefore, intra-farmer experience sharing, and support to indigenous institutions and rural tree markets should be properly promoted as potential entry points for mitigating deforestation, developing environmentally sustainable agriculture, and increasing agricultural productivity.

\section{Abbreviations}

CRGE: Climate resilient green economy; SNNPR: Southern Nations Nationalities and Peoples' Region; OFATR: Conservational tree growing; FAMS: Family size; AGE: Household head's age; GEND: Gender; ACLF: Active labor force; EDUCCAT: Education; TGEXP: Tree growing experience; TRAIN: Training; OCCUP: Occupation variable; YTR: Cash income from tree; OCCUP: Off-farm occupations; SULNTR: Land suitability for tree growing; FARMS: Farm size; AVATR: Availability of seedling sources; HPP: High potential perennial agro-ecological zone; HPC: High potential cereal agro-ecological zone; LPC: Low potential cereal agro-ecological zone.

\section{Acknowledgements}

The Authors are grateful to the research and community development service division of Arba Minch University for its material and financial support of this research. We are also grateful to data collectors and respondents for their support in successfully conducting the survey.

\section{Authors' contributions}

The corresponding author is the major contributor from administering the data collection to writing the draft manuscript, the co-author contributed by administering the survey and editing the manuscript. Both authors read and approved the final manuscript.

\section{Funding}

This study is financed by Arba Minch University. However, the views expressed in this manuscript do not represent the position of Arba Minch University. Thus, the authors are solely responsible for any errors or omissions of this manuscript. 
Availability of data and materials

The data used for this study can be obtained from the corresponding author up on request.

Ethics approval and consent to participate

Not applicable.

Consent for publication

Not applicable.

\section{Competing interests}

The authors declare that they have no competing interests.

Author details

${ }^{1}$ Department of Economics, Arba Minch University, P.O. Box 21, Arba Minch, Ethiopia. ${ }^{2}$ Department of Economics, Wolkite University, P.O. Box 07, Wolkite, Ethiopia.

\section{Appendices}

Appendix 1

See Table 5.

Table 5 Partial and semi-partial correlations of the main factors with OFATR

\begin{tabular}{|c|c|c|c|c|c|}
\hline Variable & $\begin{array}{l}\text { Partial } \\
\text { corr }\end{array}$ & $\begin{array}{l}\text { Semi- } \\
\text { partial } \\
\text { corr }\end{array}$ & $\begin{array}{l}\text { Partial } \\
\text { corr.^2 }\end{array}$ & $\begin{array}{l}\text { Semi- } \\
\text { partial } \\
\text { corr.^2 }\end{array}$ & $\begin{array}{l}\text { Significance } \\
\text { value }\end{array}$ \\
\hline GEND & -0.0512 & -0.0434 & 0.0026 & 0.0019 & 0.3579 \\
\hline FAMS & 0.0258 & 0.0218 & 0.0007 & 0.0005 & 0.6431 \\
\hline AGE & 0.0385 & 0.0325 & 0.0015 & 0.0011 & 0.4902 \\
\hline EDUCCAT & 0.0132 & 0.0112 & 0.0002 & 0.0001 & 0.8125 \\
\hline OCCUP & 0.0360 & 0.0304 & 0.0013 & 0.0009 & 0.5188 \\
\hline ACLF & 0.0131 & 0.0111 & 0.0002 & 0.0001 & 0.8141 \\
\hline FARMS & -0.1366 & -0.1166 & 0.0187 & 0.0136 & 0.0138 \\
\hline YTR & 0.1275 & 0.1087 & 0.0163 & 0.0118 & 0.0217 \\
\hline TGEXP & 0.3821 & 0.3495 & 0.1460 & 0.1222 & 0.0000 \\
\hline AVATR & 0.0380 & 0.0321 & 0.0014 & 0.0010 & 0.4960 \\
\hline TRAIN & 0.0661 & 0.0560 & 0.0044 & 0.0031 & 0.2357 \\
\hline SULNTR & 0.1276 & 0.1087 & 0.0163 & 0.0118 & 0.0216 \\
\hline
\end{tabular}

Source: Authors' computation based on field survey

\section{Appendix 2}

\section{See Table 6.}

Table 6 Descriptive statistics of households adopted OFATR in the study year

\begin{tabular}{|c|c|c|c|c|c|}
\hline Variable & Obs & Mean & Std. dev & Min & Max \\
\hline GEND & 132 & .0530303 & .2249476 & 0 & 1 \\
\hline FAMS & 132 & 7.439394 & 2.574857 & 1 & 15 \\
\hline AGE & 132 & 45.42424 & 10.05414 & 20 & 75 \\
\hline EDUCCAT & 132 & 2.621212 & .6827236 & 1 & 4 \\
\hline OCCUP & 132 & .8181818 & .3871639 & 0 & 1 \\
\hline ACLF & 132 & 3.424242 & 1.808045 & 1 & 11 \\
\hline FARMS & 132 & 1.090801 & .975376 & .1 & 7.818 \\
\hline YTR & 132 & .4090909 & .4935391 & 0 & 1 \\
\hline TGEXP & 132 & .9924242 & .0870388 & 0 & 1 \\
\hline AVATR & 132 & .469697 & .5009821 & 0 & 1 \\
\hline TRAIN & 132 & 6893939 & .4645046 & 0 & 1 \\
\hline SULNTR & 132 & .1886341 & .2651503 & 0 & 1.25 \\
\hline HPP & 132 & .280303 & .4508583 & 0 & 1 \\
\hline HPC & 132 & .5378788 & .5004624 & 0 & 1 \\
\hline LPC & 132 & .1818182 & .3871639 & 0 & 1 \\
\hline
\end{tabular}

Source: Authors' computation based on field survey

\section{Appendix 3}

See Table 7.

Table 7 Descriptive statistics of households did not adopt OFATR in the study year

\begin{tabular}{|c|c|c|c|c|c|}
\hline Variable & Obs & Mean & Std. dev & Min & $\overline{\text { Max }}$ \\
\hline GEND & 203 & .1527094 & .3605964 & 0 & 1 \\
\hline FAMS & 203 & 6.665025 & 3.063052 & 1 & 17 \\
\hline AGE & 203 & 42.70443 & 10.90514 & 22 & 70 \\
\hline EDUCCAT & 203 & 2.423645 & .6878237 & 1 & 5 \\
\hline OCCUP & 203 & .7783251 & .4164004 & 0 & 1 \\
\hline ACLF & 203 & 2.980296 & 1.771503 & 1 & 13 \\
\hline FARMS & 203 & .978465 & 1.155389 & .0125 & 7 \\
\hline YTR & 203 & .1625616 & .3698773 & 0 & 1 \\
\hline TGEXP & 203 & .546798 & .4990358 & 0 & 1 \\
\hline AVATR & 203 & .2364532 & .4259541 & 0 & 1 \\
\hline TRAIN & 203 & .5418719 & .4994754 & 0 & 1 \\
\hline SULNTR & 203 & .1061099 & .1964438 & 0 & 1.5 \\
\hline HPP & 203 & .2807882 & .4504952 & 0 & 1 \\
\hline $\mathrm{HPC}$ & 203 & .5369458 & .4998659 & 0 & 1 \\
\hline LPC & 203 & .182266 & .387018 & 0 & 1 \\
\hline
\end{tabular}

Source: Authors' computation based on field survey 
Table 8 Estimates of logistic regression without agro-ecological dummies

\begin{tabular}{|c|c|c|c|c|c|c|}
\hline \multicolumn{5}{|c|}{ Logistic regression } & \multicolumn{2}{|c|}{ Number of obs $=335$} \\
\hline & & & & & \multicolumn{2}{|c|}{ Prob $>\mathrm{chi}^{2}=0.0001$} \\
\hline \multicolumn{5}{|c|}{ Log pseudo likelihood = -162.13686 } & \multicolumn{2}{|c|}{ Pseudo $\mathrm{R}^{2}=0.2782$} \\
\hline OFATR & Coef & Robust Std. Err & $z$ & $P>z$ & [95\% Conf. & \\
\hline GEND & -.68071 & .521727 & -1.30 & 0.192 & -1.703276 & .3418561 \\
\hline FAMS & .0430281 & .0621043 & 0.69 & 0.488 & -.0786942 & .1647503 \\
\hline AGE & .0089223 & .0146305 & 0.61 & 0.542 & -.019753 & .0375977 \\
\hline EDUCCAT & .0309713 & .2063623 & 0.15 & 0.881 & -.3734913 & .435434 \\
\hline OCCUP & .2410158 & .3420199 & 0.70 & 0.481 & -.4293308 & .9113624 \\
\hline ACLF & .0131217 & .1016852 & 0.13 & 0.897 & -.1861777 & .2124211 \\
\hline FARMS & -.3671371 & .1599601 & -2.30 & 0.022 & -.6806531 & -.053621 \\
\hline YTR & .5852743 & .3019399 & 1.94 & 0.053 & -.006517 & 1.177066 \\
\hline TGEXP & 4.376642 & 1.054511 & 4.15 & 0.000 & 2.309838 & 6.443446 \\
\hline AVATR & .1953668 & .2982566 & 0.66 & 0.512 & -.3892054 & .779939 \\
\hline TRAIN & .3873335 & .2955154 & 1.31 & 0.190 & -.1918661 & .966533 \\
\hline SULNTR & 1.590531 & .7841496 & 2.03 & 0.043 & .053626 & 3.127436 \\
\hline _cons & -5.542972 & 1.257009 & -4.41 & 0.000 & -8.006665 & -3.07928 \\
\hline
\end{tabular}

Source: Authors' computation based on field survey

Appendix 4

See Table 8.

\section{Appendix 5}

\section{See Table 9.}

Table 9 Estimates of logistic regression with agro-ecological dummies

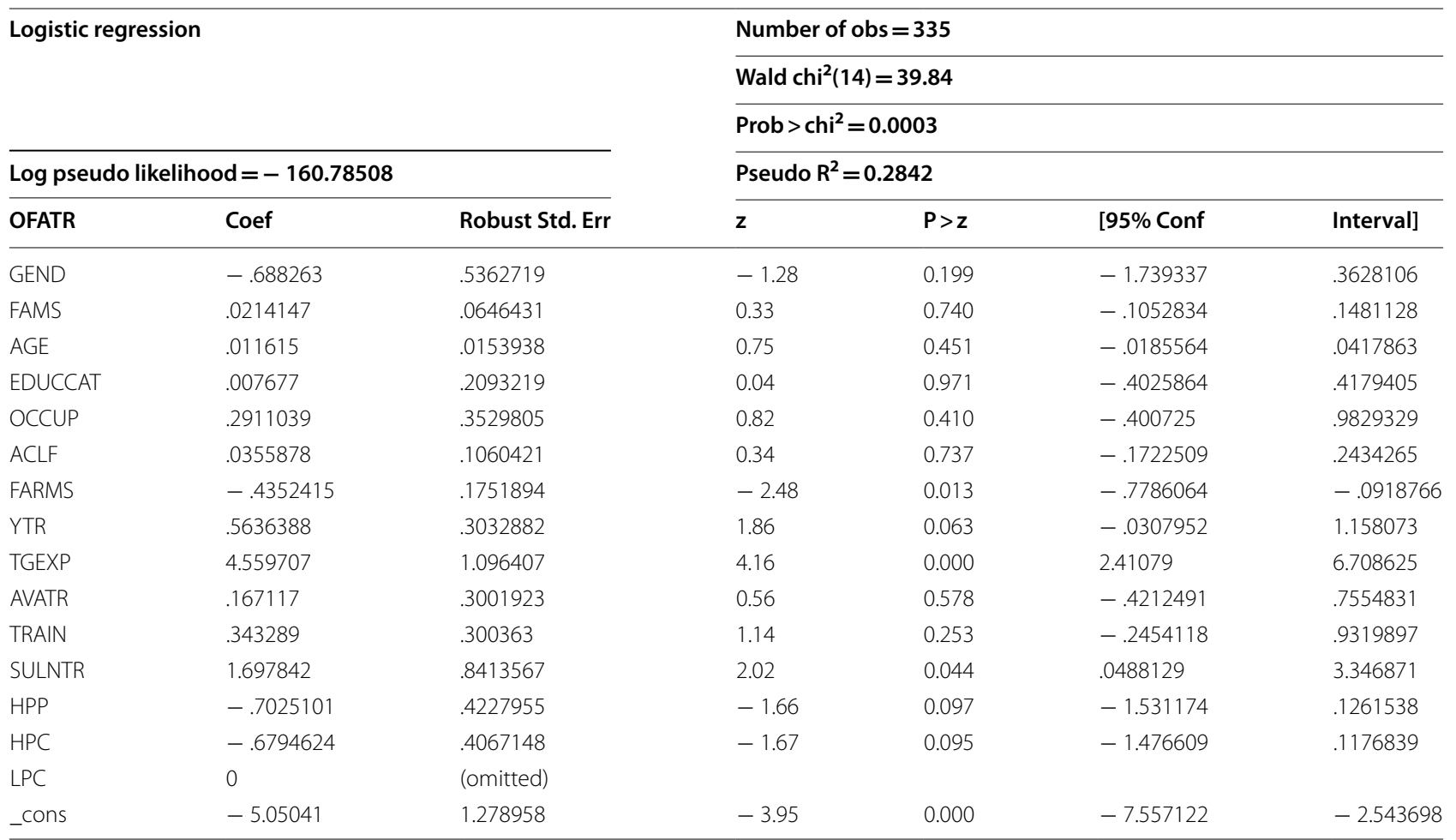

Source: Authors' computation based on field survey 
Received: 9 October 2020 Accepted: 4 December 2020

Published online: 12 January 2021

\section{References}

Abebe, SW (2000) Farmers' Private Tree Growing Traditions and Management at Wondo-Genet. MSc Thesis, Wagningen University, The Netherlands

Abebe T (2005) Diversity in home-garden agroforestry systems of southern Ethiopia. PhD Thesis, Wageningen University, the Netherlands

Abera BD (2003) Factors Influencing the Adoption of Soil Conservation Practices in North western Ethiopia. Discussion Paper 37. Institute of Rural Development. University of Gottingen, Gottingen, Germany.

Admassie Y (2000) Twenty years to nowhere: property rights, land management and conservation in Ethiopia. The Red Sea Press, Asmara

Amemiya T (1985) Advanced Econometrics. Harvard University Press, Cambridge

Asfaw A, Admassie A (2004) The role of education in the adoption of chemical fertilizer under different socio-economic environments in Kenya. Agricultural Economics 30:215-228

Bekalo S, Bangay C (2002) Towards effective environmental education in Ethiopia: problems and prospects in responding to the environment - poverty challenge. Int J Edu Dev 22:35-46

Bekele W (2005) Stochastic dominance analysis of soil and water conservation in subsistence crop production in the eastern ethiopian highlands: the case of the Hunde-Lafto area. Environ Res Econ 32:533-550

Bekele G, Mekonnen A (2010) Investments in land conservation in the Ethiopian highlands: a household plot-level analysis of the roles of poverty tenure security, and market incentives. Environment for Development Initiative, Discussion Paper Series 10-09, Environment for Development

Belsky JM (1993) Household food security, farm trees, and agro-forestry: a comparative study in indonesia and the philippines. Human Organ 52(2):130-141

Bishaw B (2001) Deforestation and land degradation in the Ethiopian highlands: a strategy for physical recovery. NEAS 8(1):7-26

Bishaw B (2009) Deforestation and land degradation in the Ethiopian highlands: a strategy for physical recovery. Ee-JRIF 1(1):5-18

Central Statistical Authority of Ethiopia (2008) Summary and statistical report of the 2007 population and housing census. Central Statistical Authority of Ethiopia, Addis Ababa

Chaves B, Riley J (2001) Determination of factors influencing integrated pest management adoption in coffee berry borer in colombian farms. Agric Ecosyst Environ 87:159-177

Deininger K, Jin S (2006) Tenure security and land-related investment: evidence from Ethiopia. EuR Econ Rev 50:1245-1277

Dercon S (2004) Growth and shocks: evidence from rural Ethiopia. J Dev Econ 74(2):309-329

Deressa TT, Hassan R, Ringler C, Alemu T, Yesuf M (2009) Determinants of farmers' choice of adaptation methods to climate change in the Nile Basin of Ethiopia. Global Environ Change 19:248-255

Desalegn D (2007) The bio cultural diversity of living indigenous sacred landscape in the gamo highlands of Ethiopia. Ethiopian Wildlife and Natural History Society, Addis Ababa

Di Falco S, Chavas J (2009) On crop biodiversity, risk exposure, and food security in the highlands of Ethiopia. Am J Agr Econ 91 (3):599-611

Di Falco S, Veronesi M, Yesuf M (2011) Does adaptation to climate change provide food security? A micro perspective from Ethiopia. Am J Agr Econ $1-18$

FAO IFAD WFP (2011) The state of food insecurity in the world: how does international price volatility affect domestic economies and food security? FAO, IFAD, WFP, Italy

Federal Democratic Republic of Ethiopia (2011) Ethiopia's climate-resilient green economy: green economy strategy. Federal Democratic Republic of Ethiopia, Addis Ababa

Feder GRE, Zilberman D (1985) Adoption of agricultural innovations in developing countries: a survey. Econ Dev Cult Change 33(2):255-298

Feder G, O'Mara GT (1981) Farm size and the adoption of green revolution technology. Econ Dev Cult Change 30:59-76

Food and Agriculture Organization of the United Nations (FAO) (1984) Ethiopian Highlands Reclamation Study. Final Report, Volumes. 1-2, Food and Agriculture Organization of the United Nations (FAO: Rome.
Food and Agriculture Organization of the United Nations (FAO) (2001) The economics of soil productivity in Sub-Saharan Africa. Food and Agriculture Organization of the United Nations (FAO), Rome

Food and Agricultural Organization of the United Nations (FAO) (2011) The State of Food and Agriculture 2010-2011: Women In Agriculture: Closing The Gender Gap For Development. Food and Agricultural Organization of the United Nations (FAO), Rome

Freeman D (2002) From warrior to wife: cultural transformation in the Gamo Highlands of Ethiopia. J R Anthropol Inst 8(1):23-44

Fulginiti LE, Perrin RK, Yu B (2004) Institutions and agricultural productivity in Sub-Saharan Africa. Agric Econ 31:169-180

Green DA, Ng'ong'ola G (1993) Factors affecting fertilizer adoption in less developed countries: an application of multivariate logistic analysis in Malawi. J Agric Econ 44(1):99-109

Griliches Z (1957) Hybrid corn: an exploration in the economics of technological change. Econometrica 25(4):501-522

Hogset H (2005) Social networks and technology adoption. Selected paper prepared for presentation at the American Agricultural Economics Association annual meeting, Providence, Rhode Island, 24-27 July 2005

Intergovernmental Panel on Climate Change (IPCC) (2007) Summary for policy makers, climate change 2007: the physical science basis. Working Group I Contribution to IPCC Fourth Assessment Report, Geneva

lqbal SMM, Ireland CR, Rodrigo VHL (2006) A logistic analysis of the factors determining the decision of smallholder farmers to intercrop: a case study involving rubber-tea intercropping in Sri Lanka. Agric Syst 87:296-312

Kassa G (2003) GIS-Based Analysis of Land Use/Land Cover, Land Degradation and Population Changes-A Study Of Boru Metero Area Of South Wello, Amhara Region. Unpublished Msc Thesis, School of Graduate Studies, Addis Ababa University.

Kassie M, Holden ST (2006) Sharecropping efficiency in Ethiopia: threats of eviction and kinship. Agric Econ 37:179-188

Kassie M, Zikhali P, Pender J, Köhlin G (2008) Sustainable agricultural practices and agricultural productivity in Ethiopia: does agroecology matter? Environment for Development, Discussion Paper Series 09-12, Environment for Development

Kassie M, Zikhali P, Manjur K, Edwards S (2009) Adoption of sustainable agriculture practices: evidence from a semi-arid region of Ethiopia. Natural Resources Forum 33:189-198

Kassie M, Zikhali P, Pender J, Kohlin G (2010) The economics of sustainable land management practices in the Ethiopian highlands. J Agric Econ 61:605-627

Kebede F, Yamoah C (2009) Soil fertility status and numass fertilizer recommendation of typic hapluustertes in the northern highlands of Ethiopia. World Appl Sci 6(11):1473-1480

Lee DR (2005) Agricultural sustainability and technology adoption: issues and policies for developing countries. Am J Agric Econ 87(5):1325-1334

Malebo M (2005) Determinants of Household Income Poverty in the Rural Areas of Chencha District: A Cross-Sectional Data Analysis. A Thesis Submitted for the requirements of BA Degree in Economics. Ethiopian Civil Service College, Addis Ababa Ethiopia.

Melillo J, Butler S, Johnson J, Mohana J, Steudler P, Luxa H, Burrows E, Bowles F, Smith R, Scott L, Vario C, Hill T, Burtoni A, Zhouj Y, Tang J (2011) Soil warming, carbon-nitrogen interactions and forest carbon budgets. Proc Natl Acad Sci USA 108:9508-9512

Mercer DE, Haggar J, Snook A, Sosa M (2005) Agroforestry adoption in the calakmul biosphere reserve, Campeche, Mexico. Small-scale Forest Econ Manag Policy 4(2):163-183

Molua E (2009) An empirical assessment of the impact of climate change on smallholder agriculture in Cameroon. Global Planet Change 67:205-208

Pender J, Gebremedhin B (2006) Land management, crop production and household income in the highlands of Tigray, northern Ethiopia: an econometric analysis. In: Pender J, Place F, Ehui SK (eds) Strategies for sustainable land management in the East African Highlands, Chapter 5. International Food Policy Research Institute (IFPRI), Washington, D.C., pp $107-140$

Pender J, Gebremedhin B (2007) Determinants of agricultural and land management practices and impacts on crop production and household income in the highlands of Tigray, Ethiopia. J Afr Econ 17:395-450

Pender J, Desta L, Kassie M, Benin S (2001a) Land degradation in the highlands of Amhara Region and strategies for sustainable land management. 
Working Paper No. 32, International Livestock Research Institute, Livestock Policy Analysis Program, Addis Ababa

Pender J, Gebremedhin B, Benin S, Ehui S (2001b) Strategies for sustainable development in the Ethiopian highlands. Am J Agric Econ 83(5):1231-1240

Pindyck RS, Rubinfeld DL (eds) (1981) Econometric models and economic forecasts. McGraw-Hill Book Company, New York

Rogers EM (1995) Diffusion of Innovations, 4th edn. The Free Press, New York Samberg LH, Fishman L, Allendorf FW (2013) Population genetic structure in a social landscape: barley in a traditional ethiopian agricultural system. Evol Appl 6(8):1133-1145

Schultz TW (1964) Transforming traditional agriculture. Yale University Press, New Haven

Sidibe M (2005) Farm-level adoption of soil and water conservation techniques in Northern Burkina Faso. Agric Water Manag 71:211-224

Tassew W (2004) The role of schooling in the alleviation of rural poverty in Ethiopia. In: Proceedings of the 25th international conference of agricultural economists (IAAE). Event Dynamics, Durban, South Africa, 16-22 August 2003

Tadesse M, Belay K (2004) Factors influencing adoption for soil conservation measures in Southern Ethiopia: the case of Gununo Area. JARTS 105(1):49-62

Tesfaye CC, Fleskens L, Sietz D, Peerlings J (2018) Land fragmentation, climate change adaptation, and food security in the gamo highlands of Ethiopia. Agricultural Economics 00:1-11
Tietenberg T (1992) Environmental and natural resource economics, 3rd edn. Harper Collins Publishers, New York

Udry CR (2009) Networks, local institutions and agriculture in africa: notes toward a research program. Yale University Department of Economics, New Haven

Verbeek M (2004) A guide to modern econometrics, 2nd edn. John Wiley and Sons Ltd, England

World Commission on Environment and Development (1987) Our common future: the brundtland commission report. Oxford University Press, Oxford

Wooldridge JM (2000) Econometric analysis of cross section and panel data. MIT Press, Cambridge

Yesuf M, Di Falco S, Deressa T, Ringler C, Kohlin G (2008) The impact of climate change and adaptation on food production in low-income countries: evidence from the Nile Basin, Ethiopia. IFPRI Discussion Paper No. 828, International Food Policy Research Institute, Washington, DC

Zeleke E, Bliss JC (2010) Tree growing by smallholder farmers in the Ethiopian Highlands. In: Proceedings of the IUFRO conference. Slovenian Forestry Institute and Slovenian Forest Service, Slovenian

\section{Publisher's Note}

Springer Nature remains neutral with regard to jurisdictional claims in published maps and institutional affiliations.

\section{Submit your manuscript to a SpringerOpen ${ }^{\circ}$ journal and benefit from:}

- Convenient online submission

- Rigorous peer review

- Open access: articles freely available online

- High visibility within the field

- Retaining the copyright to your article

Submit your next manuscript at $\boldsymbol{\nabla}$ springeropen.com 